\title{
A PRIMEIRA PRESIDENTE DO C.A. XI DE AGOSTO
}

\author{
Antonio Augusto Machado de Campos Neto \\ Chefe do Serviço Técnico de Imprensa
}

\begin{abstract}
A paixão pela Justiça, a vontade de querer mudar o mundo, através da premissa maior de que "somente com a consciência de ter de deixar a sua passagem como uma academica totalmente integrada à Faculdade de Direito, além da solidariedade a todos e a tolerância para os seus defeitos, ou, ainda, o círculo de afeto e carinho dos colegas, batalhando para que isso nunca se quebre", são algumas das virtudes que levaram Andréa Mustafa, quartanista do curso diurno, a ser a primeira mulher a ocupar a presidência do tradicional Centro Acadêmico XI de Agosto.
\end{abstract}

Poetas, romancistas, ensaistas, filósofos, juristas e jornalistas que passaram pelas Arcadas comungam até hoje o mesmo ideal de Justiça e Direito como o de Andréa Mustafa, nascida em Saint-Denis, França, hoje com 21 anos de idade.

De personalidade marcante, todavia meiga e alegre, é filha de Reinaldo Mustafa, ex-secretário da Receita Federal, gestão-1988, e de Márcia Mustafa, professora de Letras. Com eles aprendeu a gostar das literaturas nacional e internacional e de viajar, uma vez que seus pais sempre a levaram, anualmente, aos EUA. E neste país a nova presidente teve sua atenção voltada para o regime jurídico norte-americano, o anglo-saxônico, fazendo-a, a partir deste momento, dedicar-se aos estudos do Direito Comparado.

Andréa Mustafa fez o primeiro e segundo graus em Brasília, na Escola Paroquial Santo Antonio e Colégio Objetivo, respectivamente. O terceiro grau já em São Paulo, quando no ano seguinte, 1991, ingressa nas Arcadas. De imediato, é eleita, no segundo ano, para o conselho editorial da revista O Onze de Agosto e, no terceiro ano, torna-se secretária de organização do Centro Acadêmico; no ano seguinte, novamente eleita para o conselho editorial daquela revista, acumulando, ainda, a presidência da Associação Cultural e Esportiva XI de Agosto, ACORDE.

Para a jovem de olhos expressivos "é muito orgulho $e$ responsabilidade juntos, mas o que mais gosto nesta vida, embora somente com os meus 21 anos, é o do desafio". 
Indagada sobre o que os colegas achavam de ter a primeira mulher na presidência, responde taxativa e segura: Acho que essa pergunta deveria ser dirigida a eles. Jamais verifiquei um tom irônico. Para os alunos e conseqüentemente meus colegas, o que é importante mesmo é o cargo em si"

Das mulheres que mais admira cita Simone du Beauvoir e Hannah Arendt, e considera o próximo milênio repleto de modificações e recomposições sócio-políticas, aonde a mulher ocupará grande liderança na conduta da humanidade.

São Paulo, dezembro de 1998. 


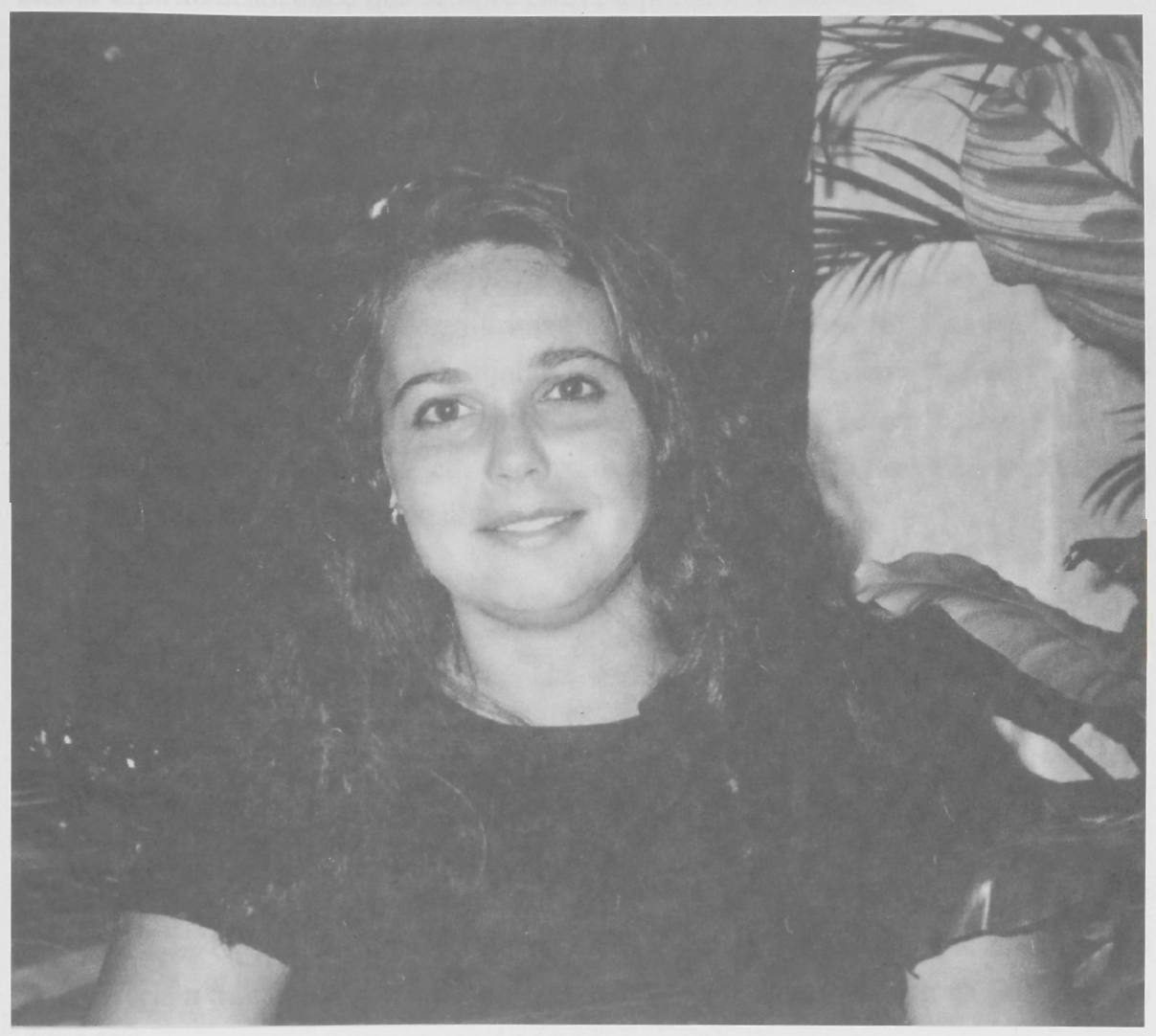

Andrea Mustafa, presidente do Centro Acadêmico XI de Agosto 